\title{
ANALISIS STRATEGI KOMUNIKASI PEMASARAN TERPADU DALAM MENINGKATAN PARTISIPASI PEMILIH PADA PEMILU 2014
}

\author{
Wira Respati \\ Marketing Communication Department, Faculty of Economics and Communication, BINUS University \\ Jln. KH. Syahdan No.9, Palmerah, Jakarta Barat 11480 \\ warespati@gmail.com
}

\begin{abstract}
As the institution in charge of election administration, Election Commission of Republic of Indonesia or Komisi Pemilihan Umum (KPU) has consistently conducted campaign to increase number of voters who will participate in election. As a matter of fact, result of previous elections showed how the level of participation has been decreased. Lack of political awareness, level of knowledge upon the importance of election as well as skepticism on government and representatives' performance were believed to be the trigger. Hence, it is important for KPU to enhance effective marketing communication program, ranging from the stages of planning, implementation and evaluation to promote public awareness to participate in the election. Therefore, this study aims to find how the principles of social marketing are actually implemented in designing communication program to increase voter awareness upon the importance of 2014 election. This study used qualitative method. Data were gathered from interview with related parties and literature study. Research found that the principles of social marketing to build awareness of voters basically have already been integrated in the programs of KPU toward the entire group of voters. In addition, KPU is quite aware of the importance of synergy between the programs of their communications both above the line and below the line. On April 9th legislative election, level of participation were increasing, reached $75.11 \%$, up from $71 \%$ in the previous 2009 election. However, the level of participation of the July $9^{\text {th }}$ presidential election dropped to $70 \%$ compared to the previous election in 2009, $72 \%$. The result of these two elections should be considered as another challenge to $K P U$ in improving their marketing communication strategy in the future.
\end{abstract}

Keywords: people participation, social marketing, integrated marketing communication

\begin{abstract}
ABSTRAK
Sebagai penanggung jawab penyelenggaraan pemilu, Komisi Pemilihan Umum Republik Indonesia wajib secara konsisten melakukan kampanye peningkatan partisipasi pemilih. Meskipun demikian, dalam beberapa pemilihan umum terakhir tingkat partisipasi pemilih cenderung mengalami penurunan. Belum meluasnya pengetahuan dan pemahaman tentang proses penyelenggaraan pemilu, kurangnya kesadaran politik, sikap skeptis terhadap pemimpin di lembaga perwakilan maupun pemerintah diyakini menjadi pemicunya. Oleh karena itu, penelitian ini menganalisis bagaimana KPU menyusun strategi komunikasi mulai dari tahapan perencanaan, pelaksanaan, hingga evaluasi. Prinsip-prinsip marketing sosial menjadi pendekatan dalam menganalisis bagaimana KPU merancang strategi komunikasi pemasaran dalam mengintegrasikan programprogram komunikasinya, untuk meningkatkan kesadaran pentingnya partisipasi mereka dalam mensukseskan pemilu 2014. Penelitian ini menemukan bahwa prinsip marketing sosial untuk membangun kesadaran pemilih pada dasarnya sudah terintegrasi dalam program-program komunikasi KPU kepada seluruh kelompok pemilih yang disasarnya. Selain itu KPU sudah cukup menyadari pentingnya mensinergikan program-progam komunikasi mereka baik yang bersifat above the line maupun below the line. Khusus pemilu legislatif 9 April 2014, kesadaran pemilih yang terbangun membuat tingkat partisipasi mencapai $75.11 \%$, naik dari $71 \%$ pada pemilu sebelumnya tahun 2009. Namun di sisi lain, tingkat partisipasi pemilu presiden 9 Juli 2014 turun menjadi 70\% dibanding pemilu sebelumnya tahun 2009 yakni 72\%. Pencapaian yang bertolak belakang pada dua hasil pemilu dalam satu agenda ini merupakan tantangan yang patut dicermati KPU dalam menyusun program-program komunikasinya pada pemilu-pemilu di masa mendatang.
\end{abstract}

Kata kunci: partisipasi pemilih, marketing sosial, komunikasi pemasaran terpadu 


\section{PENDAHULUAN}

Pemilihan umum (pemilu) merupakan salah satu pelaksanaan azas kedaulatan rakyat Indonesia, yang dilaksanakan secara jujur, adil, berdasarkan Pancasila dan Undang-Undang Dasar Negara Republik Indonesia tahun 1945. Suksesnya pemilu dapat ditinjau dari dua aspek. Pertama dari aspek prosedur penyelenggaraan, semua tahapan pemilu dapat terselenggara tepat waktu, tertib, aman disertai tingkat partisipasi masyarakat pemilih yang cukup tinggi. Kedua, secara substansial, pemilu dapat menghasilkan pemimpin yang mampu memenuhi aspirasi rakyat, memiliki kapabilitas serta mewujudkan kesejahteraan bagi rakyat (Joyowardono \& Supriatna, 2012). Artinya, suksesnya Pemilu 2014 akan terwujud apabila pemilih tidak hanya memiliki pemahaman dan pengetahuan yang tinggi tentang pemilu, tetapi juga mempunyai kesadaran penuh untuk turut menyukseskan pelaksanaan pemilu. Bentuk partisipasi aktif publik tersebut dapat dimulai dari membangun pemahaman dan opini yang objektif tentang pemilu, sehingga mendukung dan terlibat secara proaktif dalam setiap tahapannya. Pada akhirnya, masyarakat dengan kesadaran penuh mau menggunakan haknya sebagai warga negara untuk datang ke tempat pemungutan suara.

Gambaran di atas adalah harapan seluruh penyelenggara pemilu di Indonesia. Akan tetapi, seperti yang dilansir dalam laporan KPU, kecenderungan menurunnya tingkat partisipasi masyarakat dalam 3 pemilu nasional terakhir pemilu 1999 (92\%), pemilu 2004 (84\%), dan pemilu 2009 (71\%) menjadi salah satu tantangan yang dihadapi dalam upaya menyukseskan Pemilu 2014. Ada beberapa faktor yang disinyalir menjadi penyebab turunnya tingkat partisipasi masyarakat pada pemilu. Di antaranya adalah kurangnya kesadaran masyarakat terhadap pentingnya pemilu, apatisme masyarakat, money politic, dan buruknya kinerja anggota legislatif. Oleh karena itu, penelitian ini bertujuan untuk menganalisis bagaimana KPU menyusun strategi komunikasi untuk meningkatkan kesadaran pemilih terhadap pentingnya pemilu karena bagaimanapun juga partisipasi pemilih serta merta memberikan legitimasi terhadap hasil pemilu. Analisis strategi mencakup seluruh tahapan dari perencanaan, pelaksanaan, hingga evaluasi.

Prinsip-prinsip social marketing juga menjadi pendekatan dalam menganalisis bagaimana KPU merancang strategi komunikasi pemasaran mereka. Pendekatan ini efektif dalam menelaah upaya terkait membangun kesadaran publik. Social marketing, sebagai bagian dari ilmu marketing, telah digunakan sebagai upaya promosi hal-hal berupa konsep, ide, sikap, dan perilaku kepada masyarakat dalam rangka meningkatkan kualitas hidup mereka. Biasanya topik yang diusung berkaitan dengan hal-hal yang sifatnya non-komersial, bertujuan untuk mengangkat isu-isu sosial, dengan manfaat yang berpulang pada masyarakat itu sendiri. Social marketing adalah aplikasi dari prinsip-prinsip dan teknik marketing untuk mendorong terjadinya perubahan atau perbaikan sosial; seperti misalnya penelitian mengenai masalah kesehatan publik, isu-isu lingkungan hidup atau kebutuhan-kebutuhan sosial yang lainnya (Lefebvre, 2012:120).

Dalam kegiatan social marketing untuk meningkatkan partisipasi pemilih, KPU melaksanakan lebih dari satu program dengan memanfaatkan berbagai macam platform. Dengan kata lain, pesan dikomunikasikan melalui banyak channel atau saluran, baik secara above the line seperti iklan atau pemberitaan media elektronik maupun below the line seperti event, workshop, dan berbagai kegiatan. Peneliti mengembangkan penelitiannya dengan mengkaji apakah program atau kegiatan komunikasi pemasaran KPU sebagai inisiator saling bersinergi dan tidak tumpang tindih. Atau dengan kata lain, sejauh mana prinsip-prinsip Integrated Marketing Communication (IMC) diimplementasikan oleh KPU pada program-program peningkatan partisipasi masyarakat dalam Pemilu 2014. 


\section{METODE}

Untuk mengetahui bagaimana prinsip-prinsip komunikasi pemasaran terpadu diterapkan dalam upaya peningkatan partisipasi pemilih pada pemilu 2014, maka penulis menggunakan metode kualitatif. Hal ini disebabkan aspek yang ditekankan dalam kajian ini adalah kedalaman (kualitas) data bukan banyaknya (kuantitas) data (Kriyantono, 2012:57). Format desain penelitian ini adalah deskriptif; peneliti bertujuan untuk menggambarkan, meringkaskan berbagai kondisi, berbagai situasi atau berbagai fenomena realitas sosial yang ada di masyarakat yang menjadi objek penelitian. Selain itu, penelitian ini didukung dengan studi literatur terkait dengan strategi komunikasi yang ideal diimplementasian kepada publik — dalam hal ini masyarakat Indonesia—agar mereka dengan penuh kesadaran memberikan suara ke TPS. Tingkat partisipasi sangat penting karena, selain legitimasi, partisipasi tinggi ikut menentukan kualitas hasil pemilu 2014. Kualitas hasil pemilu tentu saja berkaitan erat dengan kualitas pemimpin Indonesia dalam kurun waktu 5 tahun ke depan.

Pengumpulan data dilakukan melalui studi pustaka. Selain itu, data diperoleh melalui wawancara dengan pihak terkait yang menyusun dan menjalankan kegiatan komunikasi kepada publik pada Komisi Pemilihan Umum (KPU) dalam menggaungkan proses persiapan hingga pelaksanaan pemilu sekaligus menggalang dukungan publik untuk menyukseskan pesta politik 5 tahunan. Data diperoleh dari para key informan atau narasumber utama yang berada pada divisi hubungan masyarakat dan partisipasi masyarakat KPU baik dalam bentuk wawancara maupun telaah dokumendokumen yang relevan.

\section{HASIL DAN PEMBAHASAN}

\section{Social Marketing}

Saat ini social marketing lebih sering digunakan untuk memengaruhi khalayak untuk mengubah perilaku mereka dalam mengentaskan permasalah kesehatan, lingkungan termasuk upaya mencegah terjadinya kecelakaan, serta ajakan berkontribusi pada masyarakat. Sedianya fungsi social marketing juga dapat berlaku dalam upaya mencari solusi masalah-masalah sosial. Kurangnya kesadaran publik berpartisipasi pada pemilu sebagai pilar demokrasi, selama ini dinilai menjadi pemicu rendahnya tingkat partisipasi. Kesadaran publik akan pentingnya pemilu kemudian menjadi tujuan utama KPU dalam menyusun program komunikasinya.

Social marketing sendiri sebagai bagian dari ilmu marketing telah digunakan sebagai upaya promosi hal-hal berupa konsep, ide, sikap, dan perilaku kepada masyarakat, dalam rangka meningkatkan kualitas hidup mereka. Biasanya topik yang diusung berkaitan dengan hal-hal yang sifatnya non-komersial, bertujuan untuk mengangkat isu-isu sosial, dengan manfaat yang berpulang pada masyarakat itu sendiri. Social marketing adalah aplikasi dari prinsip-prinsip dan teknik marketing untuk mendorong terjadinya perubahan atau perbaikan sosial; seperti misalnya penelitian mengenai masalah kesehatan publik, isu-isu lingkungan hidup atau kebutuhan-kebutuhan sosial yang lainnya (Lefebvre, 2012:120).

Lebih lanjut, Kotler menjelaskan social marketing merupakan teknologi manajemen perubahan sosial yang melibatkan desain, implementasi, dan pengendalian program-program yang bertujuan untuk meningkatkan penerimaan ide atau praktik sosial kepada satu atau lebih kelompok sasaran. Konsep-konsep seperti segmentasi pasar, penelitian perilaku konsumen, pengembangan dan pengujian konsep produk, komunikasi terarah, fasilitasi, insentif, dan teori pertukaran (exchange) untuk memaksimalkan responss dari kelompok sasaran. Para inisiator kampanye promosi sosial berupaya untuk mengejar tujuan adanya perubahan dengan keyakinan bahwa mereka akan memberikan kontribusi terhadap kepentingan baik bagi individu ataupun masyarakat (Kotler \& Roberto, 1989). 
Prinsip-prinsip pemasaran yang biasa dipakai untuk menjual produk ke konsumen dapat juga diterapkan untuk menjual ide, sikap dan perilaku. Lebih lanjut Kotler mengatakan bahwa social marketing berupaya memengaruhi perilaku sosial tidak untuk semata-mata mendapatkan keuntungan bagi pemasar, namun juga kebaikan masyarakat yang menjadi sasaran. Social marketing memiliki kesamaan dengan sektor komersial, dimana para pemasar menjual barang dan jasa, social marketer menjual "perubahan perilaku". Para agen perubahan (inisiator) biasanya menginginkan agar kelompok sasaran melakukan satu dari hal-hal berikut: menerima perilaku yang baru; menolak perilaku yang potensial; memodifikasi perilakunya sekarang; dan mengabaikan perilakunya terdahulu.

Selanjutnya Kotler et al (2002) mengatakan bahwa proses social marketing dimulai dengan melakukan riset pemasaran, untuk mengetahui segmen pasar dan keinginan, kebutuhan, keyakinan, masalah, hal-hal yang jadi perhatian dan perilaku dari setiap segmen pasar tersebut. Tahap selanjutnya adalah menetapkan target pasar, kelompok masyarakat yang dipercaya dapat dilayani dan memberikan pengaruh yang paling baik. Kemudian, tujuan yang jelas harus dibuat. Dan para social marketer juga menggunakan konsep marketing mix (4Ps) untuk memengaruhi target pasar atau khalayak tersebut, yaitu: product, price, place, dan promotion.

\section{Prinsip-prinsip Komunikasi Pemasaran Terpadu (IMC)}

Saat ini komunikasi atau Integrated Marketing Communication (IMC) tidak hanya berfokus pada penggunaan platform media mainstream seperti iklan di media cetak atau elektronik. Berkembang banyak media promosi baru untuk menyentuh target pasar yang dibidik (seperti logo merek yang konsisten, tone pesan, dan skema warna). Prinsip-prinsip IMC dapat membuat alat-alat promosi yang lebih efektif dengan tren serta gaya hidup khalayak karena penggunaan beberapa platform media dan alat-alat promosi untuk memproduksi efek "satu suara" yang koheren yang bekerja secara sinergis untuk mengomunikasikan pesan yang ingin disampaikan. Don Schultz dari Northwestern University mendefinisikan bahwa komunikasi pemasaran terpadu adalah strategi untuk merencanakan, mengembangkan, melaksanakan, mengevaluasi secara terukur, termasuk mengoordinasikan setiap usaha komunikasi brand atau nilai kepada khalayak baik internal maupun eksternal, sehingga mereka memiliki pemahaman yang sama atas nilai-nilai tersebut. (Belch \& Belch, 2009).

Proses komunikasi pemasaran sendiri dimulai dari konsumen atau calon konsumen, kemudian pemasar akan menentukan dan mendefinisikan bentuk-bentuk dan metode yang akan digunakan untuk menciptakan program komunikasi yang persuasif. Pada dasarnya komunikasi pemasaran terpadu atau IMC adalah kemampuan untuk mengirimkan pesan yang konsisten kepada khalayak. Ada upaya pengintegrasian satu atau lebih kegiatan komunikasi pemasarannya. Hal ini dapat dilakukan dengan mensinergikan fungsi advertising, public relations, direct marketing, sales promotion, internet marketing, dan sponsorships (Percy, 2008). Untuk itu melalui perencanaan strategi komunikasi pemasaran yang efektif, tujuan-tujuan spesik dari komunikasi akan optimal sehingga mendorong perubahan perilaku khalayak yang dibidik sebagaimana yang diharapkan. Jika dituangkan dalam kampanye peningkatan partisipasi pemilih pemilu, hasil yang diharapkan adalah perubahan perilaku masyarakat dari yang sebelumnya skeptis, menjadi optimis. Masyarakat sadar bahwa peran serta mereka dalam mensukseskan pemilihan umum adalah penting untuk masa depan bangsanya.

\section{Prinsip-prinsip Komunikasi Pemasaran Terpadu dalam Kegiatan Social Marketing Komisi Pemilihan Umum}

Seperti yang telah diulas sebelumnya, social marketing ditujukan untuk memengaruhi individu atau kelompok sasaran untuk mau "membeli” (dalam hal ini mengubah) ide, sikap, atau perilaku yang dipaparkan oleh social marketer. Memengaruhi dan mengubah perilaku seseorang atau kelompok bukanlah pekerjaan mudah. Upaya tersebut membutuhkan penggunaan sumber daya yang intensif; dapat mengidentifikasi dan memahami khalayak yang dibidik; termasuk mampu menilai 
media komunikasi atau alat-alat promosi yang efektif utamanya dalam misi meningkatkan partisipasi pemilih pada pemilu. Komunikasi pemasaran terpadu atau IMC menjadi salah satu cara untuk mengelola alat-alat promosi dan fungsi komunikasi yang persuasif yang melibatkan penjajaran kembali komunikasi dalam upaya KPU menggugah kesadaran masyarakat pemilih guna menyukseskan Pemilu 2014.

Merujuk pada penelitian yang dilakuan oleh Hawkins et al (2011), untuk kesuksesan suatu program kampanye social marketing, ada sejumlah prinsip komunikasi pemasaran terpadu yang harus diterapkan, di antaranya sbb. Pertama, program harus dirancang customer-focused dan tailor-made. Suatu program kampanye sosial harus berpijak pada konsumen atau calon konsumen dengan meneliti hal-hal apa saja yang relevan serta penting bagi mereka, serta metode komunikasi apa yang tepat digunakan. Selain itu, inisiator-dalam hal ini KPU—juga harus melibatkan partisipasi konsumen dalam program tersebut. Program komunikasi KPU harus berangkat dari persoalan turunnya tingkat partisipasi pemilih dalam beberapa pemilu terakhir. Apa yang memicu sikap skeptis terhadap perhelatan pesta demokrasi tersebut termasuk keengganan mereka datang untuk datang ke tempat pemungutan suara.

Kedua, strategi komunikasi dengan pendekatan holistik. Strategi tersebut membantu upaya untuk meraih tujuan dari program kampanye sosial. Seluruh aspek, dalam lingkungan, yang terkait dalam program harus diterapkan. Dengan menggabungkan berbagai konsep terkait dalam semua aspek yang relevan, konsumen akan menerima pesan yang konstan serta konsisten, termasuk melibatkan khalayak pada perubahan perilaku yang diinginkan. KPU harus jitu dalam memilih dan menyeleksi media kampanye yang digunakan agar komunikasi terpapar efektif. Agar tepat sasaran, pendekatan dilakukan dengan pola yang berbeda-beda namun tetap menyeluruh pada masyarakat calon pemilih di seluruh segmen masyarakat pemilih, yaitu: kelompok pemilih pemula, kelompok perempuan, kelompok difabilitas (penyandang cacat), kelompok termarginalkan (kelompok masyarakat terpinggirkan).

Ketiga, partisipasi para stakeholder. Melibatkan peran aktif stakeholder (pemangku kepentingan) yang terkait dalam suatu lingkungan ke dalam semua elemen kampanye sosial adalah penting. Termasuk di dalamnya menerima masukan serta umpan balik dari mereka, mengidentifikasi isu-isu yang relevan, menerapkan cara peduli untuk mengatasi masalah. Selain itu, inisiator juga harus mendorong para stakeholder untuk proaktif dalam menjalankan kegiatan kampanye ini. KPU sebagai lembaga penyelenggara pemilu yang berjenjang dari tingkat pusat, provinsi hingga kabupaten/kota harus solid dalam mengelola jaringan kerja internal termasuk eksternal. Pemangku kepentingan dapat berasal dari semua kalangan yang juga berkepentingan terhadap suksesnya penyelenggaraan pemilu. Mulai dari instansi-intansi pemerintahan, Lembaga Swadaya Masyarakat, serta semua unsur masyarakat yang ingin proses penegakan demokrasi ini berlanjut berkesinambungan. Terlebih para pemimpin yang dihasilkan pemilu akan menentuan arah dan kebijakan pembangunan bangsa dalam lima tahun ke depan.

Keempat, memengaruhi perilaku yang diinginkan ke seluruh masyarakat. Keterlibatan masyarakat juga tidak kalah penting untuk menghindari perbedaan antara apa yang dirasakan penting oleh tokoh kunci kelompok sasaran dan stakeholder atau masyarakat, terkait masalah masalah yang di atasi. KPU harus dapat merangkul masyarakat pemilih kemudian menyasarkan kampanye komunikasinya sesuai karakteristik mereka sebagai khalayak yang dibidik. Jika kampanye yang berbasis dari masyarakat untuk masyarakat ini diterapkan, akan terbangun visi bersama semua elemen memiliki kesempatan untuk mengemukakan isu-isu yang menjadi sorotan termasuk masukan pada kegiatan kampanye tersebut. Hal ini penting untuk memastikan bahwa kegiatan kampanye tersebut mendapat dukungan dari semua pihak di dalamnya. 


\section{Kampanye Peningkatan Partisipasi Pemilih untuk Pemilu 2014}

Komisi Pemilihan Umum menjadi satu dari sekian banyak lembaga pemerintahan dan lembaga swadaya masyarakat yang melakukan kampanye social marketing. Lembaga ini telah banyak menggunakan alat-alat promosi yang mendukung kampanye social marketing KPU, yaitu: menyosialisasikan proses dan tahapan penyelenggaraan Pemilu 2014 kepada seluruh masyarakat Indonesia; menciptakan pemahaman dan opini publik yang objektif mengenai kebijakan/program KPU yang terkait dengan penyelenggaraan Pemilu 2014; meningkatkan apresisasi masyarakat mengenai kinerja KPU terutama terkait dengan pelaksanaan Pemilu 2014; mendorong dan meningkatkan partisipasi masyarakat dan pemilih dalam pelaksanaan Pemilu 2014; dalam jangka panjang, merupakan upaya mewujudkan citra KPU sebagai lembaga yang berkomitmen penuh terhadap prinsipprinsip transparansi, akuntabilitas, dan partisipasi.

Kemudian sasaran kampanye peningkatan partisipasi masyarakat pada pemilu 2014 adalah tersosialisasikannya proses penyelenggaraan Pemilu 2014 kepada seluruh masyarakat Indonesia; terbangunnya pemahaman dan opini publik yang objektif mengenai kebijakan/program KPU yang terkait dengan penyelenggaraan Pemilu 2014; terbukanya wawasan publik dan kesamaan pandang tentang penyelenggaraan Pemilu 2014; meningkatnya apresisasi masyarakat mengenai kinerja KPU terutama terkait dengan pelaksanaan Pemilu 2014; meningkatnya partisipasi masyarakat dan pemilih dalam pelaksanaan Pemilu 2014; terbangunnya citra KPU sebagai lembaga yang berkomitmen penuh terhadap prinsip-prinsip transparansi dan akuntabilitas.

Berikut adalah kegiatan promosi peningkatan partisipasi pemilih above the line yang dilakukan KPU. Placement Iklan Layanan Masyarakat di media elektronik tahun 2013. KPU tercatat beberapa kali mengeluarkan iklan layanan masyarakat yang mengusung pesan-pesan pentingnya partisipasi pemilih dalam pemilihan umum sebagai tonggak pergeseran kekuasaan secara aman, damai dan demokratis. Pertama, penayangan iklan Layanan Masyarakat versi 30 detik di jam prime time sebanyak 4 spot selama 30 hari di stasiun TV: Metro TV, TV One, RCTI, SCTV, TVRI, Trans TV, Trans 7, ANTV, Kompas TV. Kedua, penayangan Iklan Layanan Masyarakat versi 30 detik di regular time sebanyak 3 spot selama 30 hari di stasiun televisi: Metro TV, TV One, RCTI, SCTV,TVRI, Trans TV, Trans 7, ANTV, Kompas TV. KetigaPenayangan Iklan Layanan Masyarakat selama 3 bulan di TV Bandara dan TV Kereta Api. Keempat, penayangan iklan Layanan Masyarakat di jam prime time, masing-masing sebanyak 6 spot selama 60 hari di Sindo Trijaya FM, RRI, dan Radio El Shinta. Kelima, penayangan Iklan Layanan Masyarakat selama 2 bulan di KBR 68H.

Placement Iklan/Advertorial di media cetak tahun 2013. Penyebaran informasi dilakukan di 10 surat kabar terbesar di Indonesia selama 3 kali untuk masa publikasi 2013 dan 2 kali informasi Daftar Calon Sementara dan Daftar Calon Tetap peserta pemilu 2014 yang menurut undang-undang KPU wajib melakukannya di media massa cetak nasional. Placement iklan dan advertorial juga dilakukan di 4 majalah dengan kelompok pembaca yang menyesuaikan dengan segmen masyarakat pemilih.

Penyebaran Informasi melalui Talkshow Pemilu di Televisi tahun 2013. Built in Content dialog pada 2 stasiun televisi berita swasta nasional dengan rating tertinggi, target audience program male female A, B, C1 usia 15+ dan 35+ yang ditayangkan Senin - Jumat pagi hari (menjelang program berita regular siang). Dialog dikemas secara ringan dan dibawakan (host) public figure dengan durasi 17-24 menit. Total 16 Episode di Metro TV dan 29 Episode di TV One, untuk penayangan tahun 2013.

Stasiun televisi pemerintah TVRI, sebanyak 25 kali tayang. Blocking Package kegiatan dialog pada stasiun televisi pemerintah nasional. Dialog bersifat national tentatif berdurasi 20-30 menit. Dalam talkshow tersebut, narasumber yang berbicara diantaranya Anggota/Pejabat Eselon I KPU dengan didampingi oleh Pakar/Praktisi/Pembicara Khusus. 
Penyebaran Informasi melalui Talkshow Pemilu di Radio tahun 2013. Menyelenggarakan kegiatan Talkshow Radio On Air di Radio yang disiarkan di stasiun radio pemerintah RRI sebanyak 12 episode dan di relai oleh Jaringan Radio tersebut secara nasional. On Air di Studio 3 Radio Berita Swasta dan berjaringan sebanyak di jam prime time, yang disiarkan di stasiun radio swasta dan di relai oleh Jaringan Radio tersebut secara nasional, dengan rincian masing-masing stasion empat episode.

Advertorial pada subkanal di 9 portal berita online dengan rating tertinggi berdasarkan hasil survei lembaga independen di 10 kota besar di Indonesia. Tema yang diangkat bersifat aktual berjumlah satu paket di setiap portal.

SMS broadcast kepada 2500 pelanggan di 5 provider seluler terbesar di Indonesia, mulai desember 2013. Isi SMS berkenaan dengan tanggal 9 April 2014 yang tak lain adalah hari pelaksanaan pemungutan suara.

Event Live Broadcast Gebyar Pemilu. Penyebarluasan Informasi Pemilu 2014 melalui Blocking/Enlighment atau mata program acara hiburan atau Gebyar yang mengangkat konsep dan tema pemilu. Melalui program ini diharapkan mampu meningkatkan pengetahuan dan pemahaman masyarakat luas tentang proses penyelenggaraan Pemilu 2014. Program yang disiarkan langsung ini di tiga stasiun televisi, TVRI, Kompas TV, dan Metro TV dengan masa tayang Juli sampai Desember 2013.

Pengadaan Media Sosialisasi. Dalam bentuk Poster, Spanduk, Standing Banner, Booklet, leaflet, alat peraga hingga seminar kit. Adapun desain, konten informasi serta jumlah produksinya disesuaikan dengan kebutuhan KPU Pusat, KPU Provinsi dan KPU Kabupaten/Kota, dalam menghelat program-program kampanyenya baik secara above the line maupun below the line. Ada sinergi yang cukup baik antara proses pengadaan media sosialisasi yang di integrasikan dengan kegiatan promosi diberbagai tools atau saluran komunikasi.

Media Center \& Hubungan dengan media massa. Pengadaan fasilitas Media Center merupakan hal yang penting dilakukan, agar penyebaran informasi Pemilu dapat berlangsung massif. Pasalnya fasilitas ini membantu pihak ke-3 dalam hal ini insan media atau pers dalam menjalankan tugasnya menyebarluaskan informasi faktual terhadap proses penyelenggaran Pemilu 2014. Pengadaan juga mencakup pers-release serta fasilitas sumber informasi lainnya. KPU juga aktif menjalin kerjasama yang dikukuhkan melalui nota kesepahaman dengan berbagai redaksi media massa.

Pemanfaatan New Media, Website KPU dan Social Media. Selain media komunikasi internal dalam bentuk buletin konvensional, kini KPU mengelola website guna mempublikasikan agenda kegiatan termasuk mempublikasikan kebijakan serta regulasi kepada publik eksternal. Meski secara desain belum optimal, website KPU dikelola secara baik dari sega infrastruktur dan konten. Khusus sosial media, tidak seperti lembaga atau instansi lainnya, KPU belum memiliki akun resmi seperti twitter maupun facebook. KPU cenderung membuka ruang agar masyarakat secara aktif mengelola sosial media sendiri dengan konten yang mereka rancang berdasarkan sentuhan kreatifitas masingmasing. Saat ini KPU berencana menggodok sebuah kompetisi guna merangsang partisipasi masyarakat membuat konten multi-media bertemakan pemilu di youtube.

Selain dari kegiatan yang disebutkan, KPU juga melakukan beberapa aktivitas below the line, yang kemudian dibahasakan sebagai gerakan mobilisasi sosial untuk ikut serta mensukseskan Pemilu 2014 di antaranya sebagai berikut. Roadshow KPU Goes to Campus di 23 universitas negeri dan swasta di Indonesia. Roadshow yang berlangsung selama Juli sampai desember 2013 sekaligus merupakan program pendidikan pemilih bagi generasi muda untuk pertamakalinya berpartisipasi dalam pemilu. Generasi muda masuk dalam segmen kelompok pemilih karenanya penting memupuk kesadaran bahwa suara mereka dalam menentukan arah pembangunan bangsa, dengan memberikan suara di TPS. Selain itu peran aktif mereka di seluruh tahapan penyelenggaraan pemilu juga mendorong suksesnya pemilu itu sendiri. 
Lomba Jingle \& Maskot Pemilu Agustus - Oktober 2013. Jingle dan maskot pemenang kemudian menjadi hak cipta KPU, untuk kemudian digunakan di berbagai program komunikasi KPU dalam menyukseskan Pemilu 2014. Hal ini sekaligus bukti adanya integrasi beberapa program komunikasi pemasaran dalam kampanye KPU meningkatkan partisipasi masyarakat.

Pentas Wayangan 2 November. Pendekatan lewat Seni Budaya tradisi masih dinilai cukup efektif untuk memaparkan pesan komunikasi kepada masyarakat. Topik pertunjukkan pun disesuaikan dengan tema pemilu, disajikan melalui tutur cerita yang menghibur dan disukai para penontonnya.

Senam Sehat di Silang Monas 24 November. Gerakan sosial masif dengan target khalayak warga ibu kota. Kegiatan baik ritual masyarakat sebenarnya dapat menjadi momentum bagi KPU untuk mensosialisasikan proses persiapan penyelenggaraan pemilu yang sedang berjalan, sekaligus ajakan untuk berpartisipasi menyukseskan pemilu 2014.

Relawan Demokrasi, merupakan program yang juga mengedepankan prinsip sosial marketing dengan melibatkan peran aktif tokoh kelompok masyarakat untuk menjadi pelopor bagi anggota masyarakat lainnya. Relawan Demokrasi terdiri dari peer group atau kelompok yang berasal dari 5 (lima) segmen pemilih strategis yang dituju yaitu pemilih pemula, kelompok agama, komunitas pinggiran, penyandang disabilitas dan perempuan. Gerakan sosial Relawan Demokrasi diharapkan mampu menularkan kesadaran positif terhadap pentingnya pemilu sekaligus menyebarluaskan proses tahapan pemilu yang tengah berlangsung. Pada akhirnya relawan-relawan pemilu ini dapat menggerakan masyarakat tempat mereka berada, agar mau menggunakan hak pilihnya dengan bijaksana serta penuh tanggung jawab, sehingga Pemilu 2014 menghasilkan pemimpin yang berkualitas.

Berdasarkan paparan tersebut dapat dilihat bahwa program-program komunikasi KPU merupakan kegiatan social marketing yang ditujukan untuk meningkatkan partisipasi pemilih yang menurun pada pemilu sebelumnya tahun 2009. Program-program didesain tidak sebatas mensosialisasikan kegiatan pemilu legislatif dan presiden pada 9 April dan 9 Juli namun juga memberikan alasan melalui tagline, mengapa pemilu itu penting dalam upaya melanjutkan roda kehidupan berdemokrasi di negeri ini. Tidak kalah penting, memberikan kesadaran bahwa partisipasi mereka sangat sifnifkan dalam memberikan legitimasi kepada pemerintah terpilih sekaligus menjaga stabilitas negara. Program komunikasi pemasaran yang dilakukan KPU sebagai bagian dari sosial marketing juga mencakup tata cara pelaksanaan pemilu, untuk memudahkan calon pemilih sekaligus mengukuhkan niar mereka untuk berpartisipasi memberikan suara.

KPU melaksanakan lebih dari satu program dengan memanfaatkan berbagai macam platform, dengan kata lain pesan di komunikasikan melalui banyak channel atau saluran baik secara above the line seperti iklan atau pemberitaan media elektronik maupun below the line seperti event, workshop dan berbagai kegiatan. Khusus pemilih pemula, KPU juga melakukan pemnafaatan media baru sekaligus mengemas informasi sesuai karakter pemilih muda, agar pesan tersampaikan secara efektif. Peneliti mengembangkan penelitiannya dengan mengkaji apakah program atau kegiatan komunikasi pemasaran KPU sebagai inisiator saling bersinergi dan tidak tumpang tindih, atau dengan kata lain sejauh mana prinsip-prinsip Integrated Marketing Communication (IMC) diimplementasikan oleh KPU pada program-program peningkatan partisipasi masyarakat dalam Pemilu 2014.

Bagaimanapun juga, menjawab apakah program komunikasi pemasaran yang diusung KPU sudah cukup efektif atau tidak perlu dilakukan penelitian lebih lanjut. Pasalnya, seperti yang dilansir oleh para komisioner KPU pada portal berita Kompas tanggal 10 Mei 2014, tingkat partisipasi pemilu legislatif 9 April 2014, berhasil mencapai naik 75,11 persen, naik dari 71 persen pada pemilu sebelumnya tahun 2009. Akan tetapi, untuk pemilu presiden 9 Juli 2009, tingkat partisipasi sebaliknya turun menjadi 70 persen dibanding pemilu sebelumnya tahun 2009 yakni 72 persen. Pencapaian yang bertolak belakang pada dua hasil pemilu dalam satu agenda ini memperlihatkan adanya variabel 
eksternal atau faktor eksternal yang ikut memengaruhi efektifitas program-program komunikasi KPU. Menurut survei yang dilakukan KPU dan harian Kompas, tingkat kepuasan masyarakat terhadap, kinerja eksekutif, legislatif dan partai politik menjadi faktor masih tingginya pemilih yang memilih tidak menunaikan hak suaranya atau golput.

\section{SIMPULAN}

Program-program kampanye peningkatan partisipasi pemilih oleh KPU sudah cukup beragam. Antara satu program dengan program lainnya sudah saling terintegrasi. Program kampanye sering mereka bahasakan sebagai gerakan sosial memiliki ciri khas tersendiri, yaitu dengan senantiasa bermitra kepada komponen masyarakat atau kelompok masyarakat potensial seperti organisasi kemasyarakatan (ormas), lembaga swadaya masyarakat (LSM), organisasi keagamaan, adat, organisasi profesi, partai politik dan juga instansi pemerintah pusat/daerah.

Kelompok masyarakat potensial yang dimaksud adalah mereka yang menjadi tokoh panutan, berpengaruh, penggerak sendi-sendi kehidupan, termasuk pioneer atau motor penggerak kelompok masyarakat tempat ia berada. Kelompok-kelompok ini perlu dirangkul untuk berperan serta di dalam berbagai bentuk kegiatan sosialisasi serta peningkatan partisipasi masyarakat pada pemilu yang akan datang. Orientasi kegiatan dari masyarakat untuk masyarakat akan lebih efektif dalam mendorong tumbuhnya kesadaran tinggi serta tanggung jawab penuh untuk menggunakan haknya dalam pemilu. Hal ini memperlihatkan bahwa prinsip-prinsip social marketing diimplementasikan oleh KPU dalam menjalankan kampanye peningkatan partisipasi pemilih, sebagai bagian dari upaya menyukseskan pemilu 2014 yang sudah di depan mata.

Selain merangkul masyarakat KPU harus piawai dalam membidik target khalayaknya. kampanye komunikasinya harus disesuaikan dengan karakteristik mereka. Saat ini pembagian segmen yang menjadi dasar bagi KPU dalam merancang program-program komunikasinya adalah; Kelompok Pemilih Pemula, Kelompok Perempuan, Kelompok Difabilitas (penyandang cacat). Serta Kelompok termarginalkan (kelompok masyarakat terpinggirkan). Jika kampanye yang berbasis dari masyarakat untuk masyarakat ini diterapkan, maka akan terbangun visi bersama semua elemen memiliki kesempatan untuk mengemukakan isu-isu yang menjadi sorotan termasuk masukan pada kegiatan kampanye tersebut. Hal ini penting untuk memastikan bahwa kegiatan kampanye tersebut mendapat dukungan dari semua pihak di dalamnya.

Sejauh ini komunikasi KPU dalam kampanye peningkatan partisipasi pemilih sudah cukup berjalan konsisten dan persuasif, ada keterpaduan antara satu program dengan program lainnya dengan kata lain ada upaya pengintegrasian satu atau lebih kegiatan komunikasi pemasarannya. Ada sinergi yang cukup baik antara kegiatan kampanye bersifat above the line maupun yang bersifat below the line. Namun begitu masih terlalu dini untuk mengevaluasi secara terukur, efektifitas kampanye peningkatan partisipasi pemilih oleh KPU ini. Meskipun demikian sejumlah sasaran kampanye realistis yang dapat disasar sejauh ini adalah tersosialisasikannya proses penyelenggaraan Pemilu kepada seluruh masyarakat Indonesia, terbangunnya pemahaman dan opini publik yang objektif mengenai kebijakan/program KPU yang terkait dengan penyelenggaraan pemilu 2014, serta terbukanya wawasan publik dan kesamaan pandang tentang penyelenggaraan pemilu 2014.

Sebagai penanggung jawab pelaksana, KPU diwajibkan secara terus-menerus melakukan langkah-langkah penyempurnaan pada proses sosialisasi termasuk kampanye peningkatan partisipasi pemilih yang sebenarnya sudah menjadi ritual 5 tahunan sekali. Tantangan rutin yang biasa ditemukan seperti belum meluasnya pengetahuan dan pemahaman tentang proses penyelenggaraan pemilu serta kecenderungan tingkat partisipasi pemilih yang menurun. Terlebih, mengingat sembagai lembaga 
negara, rencana program kerja diusulkan pertahun anggaran, sehingga membutuhkan perencanaan yang matang sekaligus keluwesan perubahan angaran, jika belakangan perlu dilakukan modifikasi program sesuai dengan situasi dan kondisi terakhir.

Untuk itu melalui perencanaan strategi komunikasi pemasaran yang efektif, tujuan-tujuan spesik dari komunikasi akan optimal sehingga mendorong perubahan perilaku khalayak yang dibidik sebagaimana yang diharapkan. Jika dituangkan dalam Kampanye peningkatan partisipasi pemilih pemilu, hasil yang diharapkan adalah perubahan perilaku masyarakat dari yang sebelumnya skeptis, menjadi optimis. Masyarakat pada kahirnya sadar bahwa peran serta mereka dalam mensukseskan pemilihan umum adalah penting demi masa depan bangsanya.

Perbedaan tren partisipasi pemilih pada pemilu legislatif fan pemilu presiden, encapaian yang bertolak belakang memperlihatkan adanya faktor-faktor lain yang ikut memengaruhi keberhasilan program komunikasi pemasaran KPU. Oleh karena itu penelitian lanjutan perlu dilakukan untuk menemukan variabel-variabel lain yang memengaruhi keberhasilan KPU dalam meningkatkan tingkat kesadaran pemilih untuk memberikan suaranya. Selain itu mengukur efektifitas komunikasi pemasaran yang sudah ada juga dapat menjadi opsi penelitian lainnya, sebagai dasar menyempurnakan program komunikasi pemasaran KPU pada masa-masa mendatang.

\section{DAFTAR PUSTAKA}

Aritonang, D. R. (2014, 10 Mei). KPU: Partisipasi Pemilih di Pemilu Legislatif 2014 Capai 75,11 Persen. Diakses dari http://kompas.com

Aritonang, D. R. (2014, 23 Juli). Ternyata Tingkat Partisipasi dalam Pilpres Menurun Dibandingkan Pileg. Diakses dari http://kompas.com

Belch, G. E., \& Belch, M. A. (2009). Advertising and Promotion: An Integrated Marketing Communications Perspective (8th ed). New York: McGraw-Hill.

Hawkins, J., Bulmer, S., \& Eagle, L. (2011). Evidence of IMC in social marketing. Journal of Social Marketing, 1(3), 228-239.

Joyowardono, S., \& Supriatna (Eds). (2012). Pedoman Umum Peningkatan Partisipasi Masyarakat Dalam Pemilihan Umum. Jakarta: Biro Teknis \& Hupmas KPU

Komisi Pemilihan Umum (KPU). (2012). Pemilu dalam Angka. Jakarta: Biro Teknis \& Hupmas KPU

Kotler, P., Roberto, N., \& Lee, N. (2002). Social Marketing: Improving the Quality of Life (2nd ed). California: Sage.

Kotler, P., \& Roberto, E.L. (1989). Social Marketing: Strategies for Changing Public Behavior. New York: The Free Press Macmillan.

Kriyantono, R. (2012). Teknik Praktis Riset Komunikasi. Jakarta: Kencana.

Lefebvre, R. C. (2012). Transformative social marketing: co-creating the social marketing discipline and brand. Journal of Social Marketing, 2(2), 118-129.

Percy, L. (2008). Strategic Integrated Marketing Communication: Theory and Practice. UK: Elsevier. 